DOI: https://doi.org/10.24127/ajpm.v10i2.3681

\title{
BAGAIMANA PEMAHAMAN KONSEP MATEMATIKA SISWA PADA PEMBELAJARAN ONLINE?
}

\author{
Mayya Shofa Mahfud ${ }^{1 *}$, Mardiyana ${ }^{2}$, Laila Fitriana ${ }^{3}$ \\ ${ }^{1 *}$ Mathematics Education, Universitas Sebelas Maret, Surakarta, Indonesia \\ ${ }^{2,3}$ Faculty of Teacher Training and Education, Universitas Sebelas Maret, Surakarta, \\ Indonesia \\ ${ }^{*}$ Corresponding author. \\ E-mail: $\quad$ mayyas.msm@student.uns.ac.id ${ }^{\left.{ }^{*}\right)}$ \\ mardiyana@staff.uns.ac.id ${ }^{2)}$ \\ lailafitriana_fkip@staff.uns.ac.id ${ }^{3)}$
}

Received 17 April 2021; Received in revised form 16 June 2021; Accepted 29 June 2021

\begin{abstract}
Abstrak
Penelitian ini bertujan untuk mengetahui perbedaan pemahaman konsep berdasarkan gender pada saat pembelajaran online yang bertempat di SMP Negeri 2 Patebon. Penelitian ini menggunakan penelitian deskriptif kualitatif. Pemilihan Subjek dengan purposive sampling. Data di peroleh dengan memberi soal pemahaman konsep kepada siswa kemudian melakukan wawancara secara daring. Hasil penelitian ini menunjukkan Siswa laki-laki cenderung ceroboh, namun memiliki keyakinan yang tinggi bahwa jawabannya yang dimilikinya sudah benar, dan memiliki pemahaman matematika lebih cepat. Siswa perempuan memiliki emosi yang berlebihan sehingga dalam memahami konsep matematika dibutuhkan waktu, dan memiliki rasa cemas yang lebih ketika dihadapi dengan masalah matematika. Indikator pemahaman konsep yang belum tercapai adalah siswa dapat menggunakan dan memanfaatkan serta memilih prosedur atau operasi tertentu atau algoritma pada pemecahan masalah. Perempuan memiliki pemahaman konsep kurang dibandingkan dengan laki-laki, namun laki-laki memiliki tingkat kecerobohan yang tinggi dibandingkan perempuan.
\end{abstract}

Kata kunci: Gender; matematika; online; pemahaman konsep.

\begin{abstract}
This study aims to determine differences in understanding concepts based on gender during online learning at SMP Negeri 2 Patebon. The method used in this research is descriptive qualitative. The subjects are chosen by using purposive sampling. The data obtained by giving questions to students and interviewed them online by then. The result shows that male students tend to be careless but they have conviction of that their answers are true and they have faster understanding in Mathematics. Female students have copious emotion so that they need more time to understand the concept and feel more anxious while they are given Mathematical problems. The indicators of conceptual understandings that have not understood yet are that students can use and utilize and also choose the procedure or certain operation method or algorithm on solving the problems. Female students are lack of conceptual understanding compared to male students, but male students have higher level of carelessness than female students.
\end{abstract}

Keywords: Conceptual understanding; gender; mathematics; online.

This is an open access article under the Creative Commons Attribution 4.0 International License

\section{PENDAHULUAN}

Pandemi covid-19 yang terjadi di seluruh dunia membuat semua proses kegiatan dilakukan dengan online, termasuk kebijakan yang diambil oleh pemerintah Indonesia yaitu membatasi 
semua aktivitas pendidikan secara fisik dan diganti dengan alternatif berupa pembelajaran yang dilaksanakan secara online (Purwanto et al., 2020). Pembelajaran secara online menjadikan siswa belajar mandiri dan saat proses belajar memerlukan alat bantu berupa gawai ataupun laptop (Firman \& Rahayu, 2020). Pembelajaran secara online akan mempengaruhi perilaku belajar, memahami mata pelajaran dan hasil belajar (Series, 2021). Belajar online menjadikan siswa belajar dengan serius dan untuk meminimalisir kesulitan dalam memahami materi (Lestari, Aisah, \& Nurafifah, 2020).

Kendala dalam pembelajaran online adalah penguasaan teknologi, keterbatasan sarana dan prasarana, jaringan internet, dan pembiayaan yang cukup mahal (Sofyan, Isnantyo, Fu'Adi, \& Pratama, 2020). Pada pembelajaran online siswa mengalami kesulitan dalam merumuskan pemahaman konsep (Puspitasari, Mufit, \& Asrizal, 2021). Pembelajaran online pada matematika dianggap siswa sebagai pembelajaran yang sulit, membosankan dan menakutkan (Nurjanah, Mulyaning, \& Nurlaelah, 2021).

Tujuan awal belajar Matematika yaitu memahami konsep Matematika (Nasution \& Hafizah, 2020). Kemampuan dalam menerjemahkan, menjelaskan dari bahasa matematika ke bahasa sendiri, serta mampu menerapkannya dipermasalahan seharihari, dan yang lebih penting adalah dapat mengaitkan antara satu konsep dengan konsep lainnya atau kemampuan memahami konsep Matematika (Febriani, Widada, \& Herawaty, 2019). Ketika Indonesia masih melaksanakan pembelajaran offline, Indonesia memperoleh hasil TIMSS yaitu berada pada urutan 5 terendah dari 50 negara pada tahun 2015. Pada PISA
2018, untuk nilai matematika indonesia berada pada urutan ke 72 sekian dari 78 Negara. SMP Negeri 17 Kendari pada tahun ajaran 2017/2018 memiliki kemampuan pemahaman yang rendah yaitu sebanyak $87 \%$ siswa (Fajar, Kodirun, Suhar, \& Arapu, 2019). Pada mengaplikasikan konsep matematika dalam kehidupan sehari-hari di SMP IT Al-Ma'arif pekanbaru pada tahun ajaran 2017/2018 masih rendah (Aida, Kusaeri, \& Hamdani, 2017). Pada tahun 2019, penelitian yang dilakukan Sari (Sari, Usodo, \& Pramudya, 2019) memaparkan tentang pemahaman konsep matematika pada ketimpangan materi masih buruk. Berdasarkan survey yang dilakukan dengan guru matematika di SMP 2 Patebon pada saat pembelajaran online, banyak siswa yang belum memahami konsep matematika, tidak mampu mengartikan simbol, tabel, diagram, gambar, grafik, serta kalimat matematika dan siswa tidak dapat menerapkan konsep matematika dalam masalah matematika. Hal tersebut mengakibatkan kemampuan siswa dalam memahami konsep matematika masih sangat rendah. Hal ini dipengaruhi oleh proses pembelajaran yang saat ini berlangsung, yaitu pembelajaran secara online.

Konsep matematika dibutuhkan untuk meningkatkan penguasaan ilmu pengetahuan yang dapat digunakan dalam memecahkan masalah (Kusumaningsih, Saputra, \& Aini, 2019). Indikator pemahaman konsep yaitu siswa dapat menyatakan ulang sebuah konsep, siswa dapat mengklasifikasikan objek menurut sifat-sifat tertentu sesuai dengan konsepnya, siswa dapat membedakan contoh dan yang bukan contoh, siswa dapat menyajikan konsep dalam berbagai bentuk representasi matematis, siswa dapat mengembangkan syarat perlu dan syarat 
cukup dari suatu konsep, siswa dapat menggunakan dan memanfaatkan serta memilih prosedur atau operasi tertentu dan siswa dapat mengaplikasi-kan konsep atau algoritma pada pemecahan masalah

Memahami konsep matematika dipengaruhi oleh beberapa faktor, salah satunya gender. Ada perbedaan antara laki-laki dan perempuan dalam merespon masalah matematika yang berkaitan dengan konsep matematika.

Sedangkan penelitian yang dilakukan Rahmat winata (2020) menjelaskan bahwa perbedaan gender mempengaruhi pemahaman konsep matematika. Laki-laki dengan minat belajar tinggi memiliki kemampuan pemahaman yang tinggi, sedangkan laki-laki yang memiliki minat belajar sedang dan cukup memiliki kemapuan pemahaman konsep matematika cukup. Berbeda dengan perempuan, yang memiliki minat belajar tinggi memiliki pemahaman konsep yang cukup baik, siswa perempuan yang memiliki minat sedang memiliki pemahaman konsep yang baik, dan siswa perempuan yang memiliki pemahaman konsep rendah memiliki kekurangan dalam memahami konsep matematika.

Pentingnya pemahaman konsep matematika, sehingga diperlukan adanya analisis rendahnya pemahaman konsep yang di miliki siswa laki-laki maupun perempuan pada pembelajaran online. Tujuan penelitian ini adalah untuk mengetahui bagaimana pemahaman konsep matematika siswa pada pembelajaran online.

\section{METODE PENELITIAN}

Penelitian ini menggunakan metode penelitian deskriptif kualitatif. Penelitian dilakukan di SMP Negeri 2 Patebon, pada semester ganjil tahun pelajaran 2020/2021. Sampel penelitian ini adalah siswa kelas XII. Subjek Penelitian ini adalah 2 siswa perempuan dan 2 siswa laki-laki kelas XII dengan pemilihan subjek yaitu dengan teknik purposive sampling. Pengambilan subjek berdasarkan pertimbanganpertimbangan tertentu (pertimbangan dari guru mata pelajaran dan pertimbangan dari nilai siswa). Pengumpulan data dilakukan dengan memberikan tes dan wawancara.

Instrument dalam penelitian ini adalah tes dengan soal pemahaman konsep matematika, berdasarkan indikator pemahaman konsep. Indikator yang digunakan yaitu siswa dapat menyatakan ulang sebuah konsep, dapat mengklasifikasikan objek menurut sifatsifat tertentu sesuai dengan konsepnya, dapat memberi contoh dan bukan contoh, dapat menyajikan konsep dalam berbagai bentuk representasi matematis, dapat mengembangkan syarat perlu dan syarat cukup dari suatu konsep, dapat menggunakan dan memanfaatkan serta memilih prosedur atau operasi tertentu dan dapat mengaplikasikan konsep atau algoritma pada pemecahan masalah. Masing-masing indikator diberikan 1 soal untuk mengetahui pemahaman konsep siswa dan soal-soal tersebut berbentuk soal uraian. Untuk mendapatkan data yang valid dilakukan tes soal pemahaman konsep dan wawancara.

Wawancara dilakukan untuk menggali lebih dalam pemahaman konsep siswa. Wawancara pada penelitian ini menggunakan HP dan untuk memperkuat data penelitian ini menggunakan metode triangulasi. Data jawaban siswa dikatakan valid jika sesuai dengan hasil wawancara. Wawancara dilakukan setelah siswa diberi soal untuk mengetahui alasan siswa, kemudian dianalisis untuk menghasilkan sebuah kesimpulan. Hasil 
wawancara dan tes di analisis sampai tujuan penelitian tercapai. Teknik analisis data dilakukan dengan pengumpulan data, reduksi data, penyajian data dan penarikan kesimpulan.

\section{HASIL DAN PEMBAHASAN}

Pembelajaran matematika pada saat penelitian dilakukan di SMP $\mathrm{N} 2$ Patebon dilakukan dengan daring melalui Whatsapp grup dan video pembelajaran. Pengambilan data dilakukan dengan memberikan soal tes kemudian melakukan wawancara. Soal yang diberikan berdasarkan indikator pemahaman konsep.

Berikut merupakan soal pertama "Pada hari minggu Andi bermain hujan, keesokan harinya Andi sakit. Ibu membawa Andi ke klinik untuk di periksa. Dokter memberikan Andi obat panas diminum $3 \times 1$ sehari, dan vitamin diminum $2 \times 1$ sehari. Tuliskan arti $3 \times 1$ dan $2 \times 1$ dan jelaskan apa maksudnya?". Adapun jawaban dari subjek (S1) perempuan dapat dilihat pada Gambar 1.

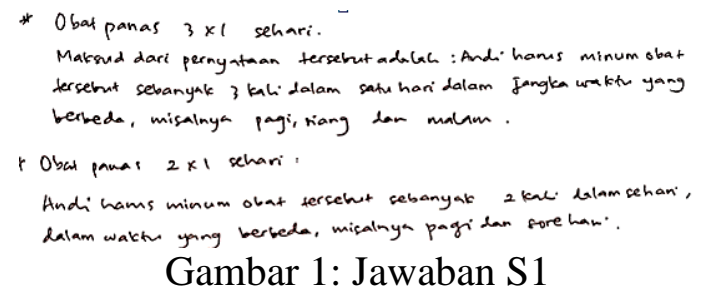

Selanjutnya, untuk hasil wawancara subjek S1 perempuan adalah sebagai berikut :

$\mathrm{P}$ : " Bagaimana kamu mengerjakan soal tersebut?"

S1 : "Membaca soal kemudian menyimpulkannya"

P : "Apakah kamu merasa cemas dalam mengerjakan soal?"

S1 : "Saya merasa sedikit was-was karena masih banyak soal yang belum selesai"
Hasil jawaban dan wawanacara menunjukkan subjek S1 bisa memahami soal namum memiliki rasa cemas karena masih banyak soal yang harus dikerjakan dengan waktu yang singkat. Indikator pemahaman konsep tentang mampu menyatakan ulang suatu konsep dan mampu merepresentasikan ke dalam bahasa sendiri sudah tepenuhi karena $3 \times 1$ artinya diminum 3 kali dalam sehari, $2 \times 1$ artinya diminum dua kali dalam sehari.

Selanjutnya, untuk soal kedua adalah sebagai berikut: "Seekor katak mula-mula dititik 0. Katak tersebut dapat melompat kekiri maupun kekanan. Sekali melompat jauhnya 4 satuan. Jika katak melompat dua kali ke kanan, kemudian 3 kali ke kiri, maka katak tersebut sampai dititik? ". Adapun jawaban subjek perempuan disajikan pada Gambar 2 .

\section{Dari 0 ke-3 ke 2: Jawnobanya 2}

Gambar 2: Jawaban S2

Gambar 2 menunjukkan S2 bahwa jawaban S2 belum sesuai dengan langkah-langkah yang seharusnya. Langkah-langkah yang perlu diperhatikan yaitu bahwa katak sekali melompat jauhnya 4 satuan. Karena melompat ke kanan 2 kali maka $2 \times 4=8$, dan ke kiri 3 kali maka $3 \times 4=12$. Karena ke kanan (+) dan ke kiri (-) maka $8-12=$ -4 . Hal ini menunjukkan S2 belum memahami soal dengan baik. Sejalan dengan jawaban subjek S2, berikut hasil wawancara terhadap subjek S2.
$\mathrm{P}$ : "Bagaimana cara kamu menyelesaikan soal tersebut?"
S2 : "Menuliskan dari 0 mula-mula katak berada, karena katak melompak kekiri 3 kali berarti -3 dan ke kanan 2 kali berarti 2" 
DOI: https://doi.org/10.24127/ajpm.v10i2.3681

P : "Dari mana jawaban 2?"

S2 : “ Karena kalo kekanan hasilnya positif, hasilnya dipilih dari angka yang positif"

P : “ Apakah kamu merasa cemas dalam mengerjakan soal"

S2 : "Saya merasa cemas karena saya belum mengetahui jawaban saya benar atau salah"

Hasil wawancara menunjukkan subjek belum bisa memahami konsep matematika pada indikator kedua yaitu siswa tidak dapat mengklasifikasikan objek menurut sifat-sifat tertentu dengan konsepnya dalam mengoperasikan bentuk matematika dan memiliki rasa cemas dalam mengerjakan soal. Hal ini sejalan dengan Sari (2019) siswa belum mampu mengoperasikan bentuk matematika. Siswa cenderung cemas dalam menyelesaikan soal.

Berikutnya, untuk soal ketiga adalah sebagai berikut: "Hitunglah hasil operasi: $6-(9): 3+(-5) \times 2$ ". Adapun jawaban subjek (S3) laki-laki dapat dilihat pada Gambar 3.

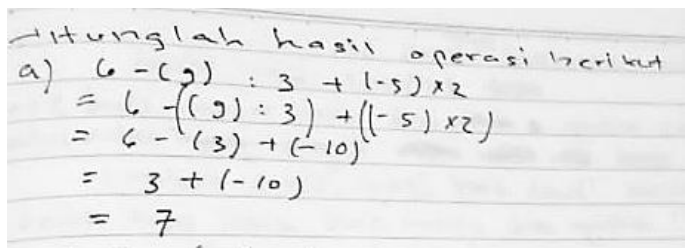
Gambar 3: Jawaban S3

Berdasarkan Gambar 3, S3 telah menjawab soal, namun ada kendala ketika menyelesaikan jawaban. S3 seperti kebingungan dalam menentukan antara perkalian, penjumlahan, pembagian atau pengurangan dulu yang harus dikerjakan. Berikut hasil wawancara dengan S3.

$\mathrm{P}$ : "Bagaimana cara kamu mengerjakan soal tersebut?"
S3 : "Pertama dikerjakan pembagian dulu baru perkalian kemudian pengurangan atau penjumlahan."

P : "Mana yang lebih dulu dikerjakan, penjumlahan atau perkalian"

S3 : "Yang harus dikerjakan dulu yaitu pembagian atau perkalian dulu"

P : “jika ada penjumlahan, perkalian kemudian ada pengurangan dan pembagian seperti mana yang kamu pilih untuk mengerjakan pertama kali?

S3 : "Yang harus dikerjakan dulu, perkalian atau pembagian, kemudian penjumlahan atau pengurangan tergantung soalnya"

P : "Apakah kamu sudah meneliti jawabnya?"

S3 : "Sudah saya merasa jawaban saya benar."

P : "Apakah kamu merasa cemas dalam mengerjakan soal?, mengapa"

S3 : Tidak, saya bisa mengerjakan karena saya memahami bagaimana cara pengerjakannya"

Berdasarkan hasil wawancara terlihat bahwa siswa mampu memilih prosedur sesuai dengan konsep matematika. Untuk menyelesaikan soal seperti itu adalah mendahulukan pembagian, perkalian terlebih dahulu sebelum mengurang atau menambah. Indikator tentang siswa dapat mengembangkan syarat perlu dan syarat cukup dari suatu konsep sudah tercapai.

Pembahasan selanjutnya terkait soal nomor 4. Berikut merupakan soal nomer 4, yaitu: "Ibu membeli 1 buah pizza dengan ukuran jumbo dan sudah 
DOI: https://doi.org/10.24127/ajpm.v10i2.3681

di potong manjadi 8 slice. Ani akan membagikan potongan pizza yang dibeli oleh ibunya, jika ani memiliki satu adek, dan akan membagi rata pizza kepada anggota keluarganya termasuk ibu dan ayahnya, berapa potong masing-masing anggota keluarga mendapatkan pizza?". Adapun jawaban S4 laki-laki disajikan pada Gambar 4.

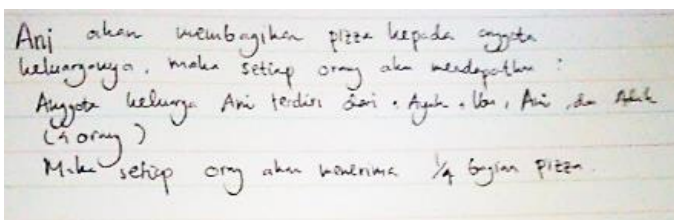

Gambar 4 : Jawaban S4

Berdasarkan hasil jawaban siswa S4 kemudian dilakukan wawancara, dengan hasil sebagai berikut :

$\mathrm{P}$ : "Bagaimana cara membagi pizza secara adil?"

S4 : "Karena ibu hanya membeli satu box pizza, maka saya bagi ke ayah, ibu, adek dan saya, nanti masing-masing akan mendapat bagian yang sama beartti 1 box pizza dibagi jumlah orangnya."

P : "Jadi masing-masing anggota keluarga mendapatkan berapa slice pizza? Dan bagaimana kamu mendapatkan slice itu? “

S4 : “ $\frac{1}{4}$ dan $\frac{1}{4}$ diperoleh dari pizza yang dibeli ibu itu kemudian saya bagi dengan jumlah anggota keluarga itu 4, karena anggota keluarga 4 masing masing dapat 4 slice"

P : "Apakah kamu yakin dengan jawaban?"

S4 : "Ya saya yakin jawab saya benar"

P : "Apakah kamu merasa cemas dalam mengerjakan ? Mengapa?"

S4 : "Tidak,karena saya merasa jawaban saya sudah benar
Pada tahap mengaplikasikan konsep siswa belum bisa menerapkan konsep matematika dengan masalah matematika di kehidupan sehari-hari. Hal ini selajan dengan penelitian Lestari (2020) yaitu siswa masih mencari cara dalam mengaplikasikan konsep matematika yang sesuai dan mudah (Lestari et al., 2020).

\section{KESIMPULAN DAN SARAN}

Hasil tes dan hasil wawancara pada pembelajaran online memapakan bahwa siswa kurang dalam memahami konsep matematika secara mandiri dan tidak adanya tatap muka secara langsung oleh guru. Siswa Perempuan merasa cemas dengan soal-soal yang diberikan, sedangkan siswa laki-laki merasa baik-baik saja dalam mengerjakan soal. Siswa perempuan memiliki ketepatan dalam menjawab namun memiliki emosi yang tidak stabil. Siswa laki-laki lebih stabil dalam emosi namun tidak memiliki ketepatan dalam menjawab soal. Hal ini disimpulkan bahwa siswa perempuan dan laki-laki memiliki kemampuan pemahaman yang berbeda. Ada beberapa indikator pemahaman konsep yang belum terpenuhi terutama pada tahapan pengaplikasian konsep matematika dengan masalah yang terjadi sehari-hari.

Berdasarkan kesimulan yang telah diaparkan, maka peneliti memaparkan beberapa saran seperti siswa hendaknya belajar memahami konsep matematika melalui latian soal. Guru diharapkan dapat menyampaikan materi dengan baik dan memberikan latian soal dengan berbagai macam karakter, supaya pemahaman konsep siswa juga terlatih. Bagi peneliti selanjunya perlu mempertimbangkan apa saja yang mempengarui pemahaman konsep siswa, selain perbedaan gender. 
DOI: https://doi.org/10.24127/ajpm.v10i2.3681

\section{DAFTAR PUSTAKA}

Aida, N., Kusaeri, K., \& Hamdani, S. (2017). Karakteristik Instrumen Penilaian Hasil Belajar Matematika Ranah Kognitif yang Dikembangkan Mengacu pada Model PISA. Suska Journal of Mathematics Education, 3(2), 130. https://doi.org/10.24014/sjme.v3i2. 3897

Fajar, A. P., Kodirun, K., Suhar, S., \& Arapu, L. (2019). Analisis Kemampuan Pemahaman Konsep Matematis Siswa Kelas VIII SMP Negeri 17 Kendari. Jurnal Pendidikan Matematika, 9(2), 229. https://doi.org/10.36709/jpm.v9i2. 5872

Febriani, P., Widada, W., \& Herawaty, D. (2019). Pengaruh Pembelajaran Matematika Realistik Berbasis Etnomatematika Terhadap Kemampuan Pemahaman Konsep Matematika Siswa SMA Kota Bengkulu. Jurnal Pendidikan Matematika Raflesia, 04(02), 120135.

Firman, F., \& Rahayu, S. (2020). Pembelajaran Online di Tengah Pandemi Covid-19. Indonesian Journal of Educational Science (IJES), 2(2), 81-89. https://doi.org/10.31605/ijes.v2i2.6 59

Kusumaningsih, W., Saputra, H. A., \& Aini, A. N. (2019). Cognitive style and gender differences in a conceptual understanding of mathematics students. Journal of Physics: Conference Series, 1280(4).

https://doi.org/10.1088/1742-

6596/1280/4/042017

Lestari, W. D., Aisah, L. S., \& Nurafifah, L. (2020). What is the relationship between self-regulated learning and students' mathematical understanding in online lectures during the covid-19 pandemic? Journal of Physics: Conference Series, 1657(1). https://doi.org/10.1088/17426596/1657/1/012065

Nasution, M. L., \& Hafizah, N. (2020). Development of students' understanding of mathematical concept with STAD type cooperative learning through student worksheets. Journal of Physics: Conference Series, 1554(1).

https://doi.org/10.1088/17426596/1554/1/012035

Nurjanah, S., Mulyaning, E. C., \& Nurlaelah, E. (2021). Increased mathematical relational understanding ability and self regulated learning of high school students through Edmodo online learning. Journal of Physics: Conference Series, 1806(1). https://doi.org/10.1088/17426596/1806/1/012066

Purwanto, A., Pramono, R., Asbari, M., Santoso, P. B., Wijayanti, L. M., Choi, C. H., \& Putri, R. S. (2020). Studi Eksploratif Dampak Pandemi COVID-19 Terhadap Proses Pembelajaran Online di Sekolah Dasar. EduPsyCouns: Journal of Education, Psychology and Counseling, 2(1), 1-12. Retrieved from https://ummaspul.ejournal.id/Edupsycouns/article/vie w/397

Puspitasari, R., Mufit, F., \& Asrizal. (2021). Conditions of learning physics and students' understanding of the concept of motion during the covid-19 pandemic. Journal of Physics: Conference Series, 1876(1), 012045. https://doi.org/10.1088/1742- 
DOI: https://doi.org/10.24127/ajpm.v10i2.3681

6596/1876/1/012045

Sari, D. N., Usodo, B., \& Pramudya, I. (2019). Analysis of Concept Understanding Student in Class X Inequalities Material. Journal of Physics: Conference Series, 1306(1).

https://doi.org/10.1088/17426596/1306/1/012029

Series, C. (2021). Description of student , $s$ difficulty in understanding online mathematics learning materials Description of student' $\mathrm{s}$ difficulty in understanding online mathematics learning materials. https://doi.org/10.1088/17426596/1918/4/042095

Sofyan, H., Isnantyo, F. D., Fu'Adi, \& Pratama, A. (2020). Online learning model in the pandemic time COVID 19 at SMK negeri 1 saptosari yogyakarta. Journal of Physics: Conference Series, 1700(1). https://doi.org/10.1088/17426596/1700/1/012070 